\title{
Phonological Characteristics of Early Vocabulary among Children with Cleft Palate, Late Talking Children, and Typically Developing Children
}

\author{
Minkyeong $\mathrm{Pi}^{\mathrm{a}}$, Seunghee $\mathrm{Ha}^{\mathrm{b}}$ \\ ${ }^{a}$ Graduate Program in Speech Language Pathology, Hallym University, Chuncheon, Korea \\ ${ }^{b}$ Division of Speech Pathology and Audiology, Audiology and Speech Pathology Research Institute, Hallym University, Chuncheon, Korea
}

Correspondence: Seunghee $\mathrm{Ha}, \mathrm{PhD}$ Division of Speech Pathology and Audiology, Audiology and Speech Pathology Research Institute, Hallym University, 1 Hallimdaehak-gil, Chuncheon 24252, Korea

Tel: +82-33-248-2215

Fax: $+82-33-256-3420$

E-mail: shha@hallym.ac.kr

Received: April 5, 2017

Revised: May 8, 2017

Accepted: May 14, 2017

\begin{abstract}
Objectives: Children with cleft palate (CP) and late talking children show delays in early lexical and phonological development. This study aims to compare the phonological characteristics of early vocabulary among children with $\mathrm{CP}$, late talking children, and typically developing children. Methods: The participants were 20 children with cleft palate, 20 late talking children, and 20 typically developing children. Spontaneous speech samples obtained during interaction were phonetically transcribed. Comparisons among the three groups were performed based on number of different words (NDW), consonant inventory, consonant frequencies, ratio of the initial sounds of eojoel by types, and percentage of correct initial consonants of eojeols. Results: Children with CP showed greater NDW than late talking children. Late talking children and children with CP produced significantly fewer consonants than typically developing children. Children with CP showed limited consonant inventory, which was restricted to nasals. The ratio of eojoel beginning with stops was higher in late talking children than in children with $\mathrm{CP}$, but the ratio of eojoel beginning with nasals was higher in children with CP than in late talking children. Late talking children, as compared to children with CP, had a higher percentage of correct initial consonants of eojeols. Conclusion: The results suggest that late talking children have a more limited vocabulary than children with $\mathrm{CP}$ and have delayed phonological development compared to their typically developing peers, however the accuracy of consonants is higher in late talking children than children with CP. These findings have implications for specialized intervention approaches for children with CP and late talking children.
\end{abstract}

Keywords: Early vocabulary, Phonological characteristics, Cleft palate, Late talker
생후 1 년 동안 아동은 급격한 신체 변화와 동시에 다양한 음운 발달 단계를 거친다. 아동이 음절성 발성 및 첫 낱말을 시작한 이후 로는 언어 단계로의 전환기를 맞는다. 특히 18 개월 전후로는 아동 의 단어 산출이 활발해지므로 보편적인 언어의 특징보다 모국어의 음운 체계를 반영하는 말소리가 산출된다(Locke, 1983). 아동이 음 절성 발성이나 초기 어휘를 통해 탐색해본 말소리는 이후의 어휘 산출에 영향을 미친다고 알려져 있는데, 아동의 자음 목록에 있는 음소로 이루어진 어휘는 쉽게 학습하지만, 자음 목록에 포함되지 않은 음소로 이루어진 어휘는 습득에 어려움 또는 지연을 보일 수
있다(Ferguson \& Farwell, 1975; Schwartz \& Leonard, 1982; Storkel, 2006). 따라서 이 시기 아동들의 초기 어휘에 나타난 음운 특성에 대해 숙지하는 것은 말-언어 발달의 유기적 관계를 염두에 둔 중재 의초석이 될 수 있다.

초기 음운 발달과 어휘 습득 간의 관계는 다수의 연구자에게 조 명을 받았다. 어휘 습득과 음운 발달 간의 관계를 살펴본 Storkel과 Morrisette (2002)는 아동이 새로운 단어(novel word)를 학습할 때 어휘 표상과 음운 표상이 유기적으로 작용하여 어휘 발달이 음운 발달에 영향을 미치기도 하고, 음운 발달이 어휘 발달에 영향을 주 
기도 한다는 양방향적 관계를 제시하였다. Stoel-Gammon (2011) 은 아동이 구어 발화(meaningful speech)를 산출하기 위해서는 조 음 기관의 움직임을 비롯한 음운 발달이 이루어져야 한다고 보고 하였다. 같은 맥락으로 출생부터 2세 6 개월까지의 아동은 어휘 요 인이 음운 발달에 영향을 미치는 것보다 음운 시스템의 발달이 어 휘 발달에 더 큰 영향을 미칠 것이라고 하였다. 또한 음운 발달과 관 련된 요인에는 성인 형태로 단어를 산출하기 위해 필요한 말-운동 능력 요인 및 음운 시스템의 학습과 연관된 인지-언어적 요인 모두 가 고려되어야 한다는 점을 시사하였다. Choi, Kim과 Kim (2014) 은 음운 발달에 제한이 있는 아동이 어휘 발달에도 어려움이 있을 가능성에 대해 시사하고, 어휘 능력과 음운 능력에 상관이 있다는 결과를 제시하였다.

18-30개월 아동 40명을 대상으로 한국어 초기 어휘에 나타난 음 운 특성과 말소리 빈도를 살펴본 $\mathrm{Ha}$ 와 $\mathrm{Pi}$ (2016)에 따르면, 조음위 치별 자음 산출 비율은 치경음, 연구개음, 양순음, 경구개음, 성문 음 순서로 출현하였으며 조음방법별 자음 산출 비율은 폐쇄음, 비 음, 파찰음, 마찰음, 유음 순서로 산출되었다고 한다. 전체 음소 중 장애음은 $61.65 \%$, 공명음은 $38.35 \%$ 로 보고되었다. 어절 첫 소리 유 형을 장애음과 공명음으로 나누었을 때 장애음으로 시작하는 어 절은 $44.59 \%$, 공명음으로 시작하는 어절은 $55.41 \%$ 로 나타나 한국 아동의 초기 어휘에는 모음, 비음, 유음과 같은 공명음으로 시작하 는 어휘가 상대적으로 높음을 제시하였다. 어절 첫 소리 유형을 조 음방법별로 구분해 보면 모음으로 시작하는 어절(35.22\%), 폐쇄음 으로 시작하는 어절(32.14\%), 비음으로 시작하는 어절(20.06\%), 파 찰음으로 시작하는 어절(6.70\%), 마찰음으로 시작하는 어절 (5.75\%), 유음으로 시작하는 어절(0.14\%) 순으로 출현하였다. 어절 첫 자음 정확도는 $83.06 \%$ 로 나타났다. 종합해보면, $\mathrm{Ha}$ 와 $\mathrm{Pi}(2016)$ 는 어린 아동의 자발화를 토대로 초기 음운 및 어휘 발달에 지연을 보이는 아동과 일반 아동을 비교할 수 있는 근거 자료를 제시하였 다. 따라서 말-언어 지연 측면의 고위험군인 말 늦은 아동과 구개열 아동 등을 대상으로 음운 발달 양상을 비교한 후 중재 방향에 대해 모색할 것을 제안하였다.

초기 어휘 및 음운 발달 시기에 말과 언어 측면 모두에서 현저한 지연이 관찰되는 아동들이 있다. 구조적 결함을 동반한 구개열 아 동과 장애 요인이 명확하지 않으나 표현언어 측면에서 지연을 보이 는 말 늦은 아동이 그 예이다. 먼저, 구개열 아동은 대개 생후 12 개 월을 전후로 구개성형술을 받는다. 따라서 구개열 아동은 생후부 터 구개 재건 시까지 구강 및 연인두 부위의 선천적 결함이 지속되 며, 구조적 결함이 초기 음운 발달에서 불리한 조건으로 작용한다. 일반 아동은 언어 이전기에 음절성 발성을 통해 다양한 음소를 탐
색하는데 구개열 아동은 경구개와 연구개 위치에서 산출되는 말소 리를 경험하지 못한다. 또한 구강 압력이 필요한 자음을 왜곡하여 산출할 수 있다(Peterson-Falzone, Trost-Cardamone, Karnell, \& Hardin-Jones, 2006). 구개열이 없는 또래와 비교하였을 때, 구개열 아동은 전체 발성에서 음절 구조의 형태를 갖추지 못한 전음절성 발성이 차지하는 비율이 높고 제한적인 자음 목록을 가지고 있으 며, 구강 압력이 필요한 진자음 산출 비율이 적고 성문음과 비음의 산출 비율이 높다(Chapman, 1991; Chapman, Hardin-Jones, Schulte, \& Halter, 2001; Hutters, Bau, \& Brondsted, 2001; Kim \& Ha, 2013; Moon \& Ha, 2012; Park \& Ha, 2016; Scherer, Williams, \& ProctorWilliams, 2008). 구조적 결함 요인은 구개열 아동의 음운 발달에 영향을 미칠 뿐 아니라 궁극적으로 초기 어휘 발달에 영향을 끼칠 수 있다. 이는 언어 발달에 부정적인 영향으로 이어져 구개열 아동 중 상당수가 수용언어와 표현언어 발달의 지연이 관찰된다고 알려 져 있다(Kim, Kim, \& Kim, 2002; Peterson-Falzone et al., 2006).

선행연구에서는 구개열 아동이 특정 음소로 시작하는 어휘를 기 피하거나 선호하는 특성을 보이는지 살펴보기 위해 낱말의 첫 소 리 비율과 첫 자음 정확도를 측정하였다(Estrem \& Broen, 1989; $\mathrm{Ha}, 2014 ;$ Hardin-Jones \& Chapman, 2014). 먼저 낱말 첫 소리 비 율에 대해 살펴보면, 구개열 아동은 공명음으로 시작하는 낱말 비 율이 높고 일반 아동은 장애음으로 시작하는 낱말 비율이 높았다. 특히 구개열 아동은 비음과 성문음으로 시작하는 낱말 비율이 높 은 반면, 구강 폐쇄음이나 치경음으로 시작하는 낱말 비율은 낮았 다(Willadsen, 2013). 구개열 아동의 낱말 첫 자음 정확도에 대한 연 구를 살펴보면, Estrem과 Broen (1989)은 일반 아동의 낱말 첫 자 음 정확도가 $71.2 \%$ 인 반면, 구개열 아동은 $53.6 \%$ 로 낮다는 점을 확 인하였다. 낱말의 첫 자음 정확도를 첫 소리 유형에 따라 나누어 본 연구(Hardin-Jones \& Chapman, 2014)에서는 장애음으로 시작하 는 단어의 첫 자음 정확도는 일반 아동이 높았으며, 공명음으로 시 작하는 단어의 첫 자음 정확도는 구개열 아동과 일반 아동 간의 유 의한 차이가 나타나지 않았다. 이 연구 결과들을 종합하여 보았을 때, 구개열 아동은 공명음의 산출 비율이 높은 것에서 그치지 않고 이 음소들로 시작하는 단어를 더 정확하게 많이 사용하여 공명음 으로 이루어진 어휘에 대한 선호도를 보인다고 할 수 있다.

반면에 신체적 발달 장애 요인 없이 말-언어 발달 면에서 지연을 보이는 아동이 있다. 전형적으로 발달하는 아동은 18 개월 경에 이 르면 50개 낱말을 산출할수 있다고 보고되지만(Bates, Dale, \& Thal, 1995; Chang-Song, 2004), 전체 아동 중 약 $15 \%$ 는 이 기준에 도달 하지 못 한다(Rescorla, 1989). 이 아동들은 오랜 기간 동안 말 늦은 아동(late talker)으로 분류되고 지칭되면서 말-언어 특성에 대해 많 
은 연구가 이루어졌다. 연구마다 말 늦은 아동을 정의한 기준에는 약간의 차이가 있으나 대체적으로는 표현어휘량(vocabulary size) 을 기준으로 말 늦은 아동을 설명하였다. 즉, 청력 손실이 없고 빈번 한 중이염 경험이 없으며 다른 발달 장애를 동반하지 않고 표현언 어상에서만 지연을 보이는 3 세 이전의 아동을 말 늦은 아동이라 이 르는 것이 일반적이다(Paul, 1991; Rescorla, 1989; Rescorla \& Achenbach, 2002; Thal \& Bates, 1988; Thal, Tobias, \& Morrison, 1991).

하지만 3 세 미만의 아동에게 어휘량만으로 언어 발달 지연을 판 단하는 것은 불완전하다는 판단 아래 말 늦은 아동의 특성으로 주 목받기 시작한 요인이 음운 능력이다(Paul \& Jennings, 1992; Rescorla \& Ratner, 1996; Williams \& Elbert, 2003). 말 늦은 아동의 자음 출현율이나자음 목록 수는 또래 아동에 비해 더 적다는 일관 적인 결과들이 제시되었으며(Kim, Lee, \& Lee, 2015; Hong \& Kim, 2005; Mirak \& Rescorla, 1998; Rescorla \& Ratner, 1996; Sim \& Ha, 2014; Williams \& Elbert, 2003), 산출되는 자음 유형은 폐쇄음, 비 음, 활음, 성문음으로 밝혀졌다(Rescorla \& Ratner, 1996). 또한 말 늦은 아동은 3 세 이후에 안정적으로 발달하는 마찰음, 유음, 경구 개 파찰음이 또래에 비해 지연된 출현을 보이며 음절 구조 유형은 단순 음절 구조를 주로 사용하였다는 연구 결과들이 보고되었다 (Paul, 1991; Paul \& Jennings, 1992; Rescorla \& Ratner, 1996). 만 3 세 이전에 말 늦은 아동으로 확인된 아동들의 3 세 이후의 조음능 력을 살펴본 연구에 따르면 표준화된 발음 평가 도구에서 $10 \% \mathrm{ile}$ 미만의 수행력을 보이는 아동이 3 세에 $50 \%, 4$ 세에 $34.4 \%$ 로 나타났 다. 따라서 초기 음운 발달 지연이 영유아기 이후에도 심도의 조음 장애와 함께 낮은 말명료도로 이어질 수 있음을 보여주었다(Paul, 1993; Rescorla \& Schwartz, 1990).

위 연구들에서 공통적으로 제시하는 바는 말 늦은 아동이 표현 어휘량 뿐만 아니라 음운 발달에서도 지연을 보인다는 것이며 음 운 능력을 언어 발달 예측 요인으로 보았다는 것이다. 즉, 말 늦은 아동일지라도 자음 목록 수가 다양하고 말소리 산출에 안정성이 있으면 이후 말-언어 발달에 긍정적인 예후를 보일 수 있다. 또한 어 휘량은 말 늦은 아동을 확인하기 위한 단일 진단적 지표로 완전하 지 않기 때문에 음운 측면의 평가가 중요하다는 점을 시사한다(Paul, 1991; Shin \& Lee, 2015; Thal, Oroz, \& McCaw, 1995; Williams \& Elbert, 2003).

구개열 아동과 말 늦은 아동의 장애 요인은 구조적인 문제와 기 능적인 문제로 구별된다. 하지만 30 개월 이전에는 두 아동 모두 표 현어휘가 제한적이고 음운 발달이 지연되어 유사한 임상적 특징을 보인다. 그러므로 말 늦은 아동과 구개열 아동 모두 어휘와 음운 측 면에 초점을 맞춘 중재가 필요하다. 장애 원인은 뚜렷하게 구별되지
만 동일한 언어 영역에서 유사한 문제를 보이는 두 아동 집단을 서 로 면밀하게 비교하는 연구는 두 장애의 특성에 대한 이해를 보다 넓히고 장애 특성을 고려한 전문적인 중재를 제공할 수 있는 근거 를 제시할 것이다. 따라서, 본 연구는 18-30개월 구개열 아동, 말 늦 은 아동, 일반 아동의 자발화에 기초하여 서로 다른 낱말 수, 자음 목록 수, 조음위치 및 조음방법별 자음 산출 비율, 어절 첫 소리 유 형, 어절 첫 자음 정확도를 살펴보았다. 이를 통해 초기 어휘에 나타 난 음운 특성을 일반 아동과 비교하고 구개열 아동과 말 늦은 아동 의 음운 발달양상에 어떠한 차이점이 있는지 살펴보았다.

\section{연구방법}

\section{연구대상}

본 연구는 18-30개월 사이에 있는 구개열 아동 20명, 말 늦은 아 동 20 명, 일반 아동 20 명으로 하였다. 구개열 아동은 대학 병원 구개 열 클리닉에서 1 차 구개성형술을 받았으며 구개열 혹은 구순구개 열 이외에 (1) 염색체 이상으로 인한 증후군이 없고, (2) 뚜렷한 인 지, 신경, 발달과 관련된 의학적 진단을 받지 않았으며, (3) 영아선별 교육진단검사(DEP; Jang, Seo, \& Ha, 2008)에서 의사소통 영역을 제외한 전체 영역이 백분위 $35 \%$ ile 이상으로 정상 발달에 속하였다.

말 늦은 아동은 양육자로부터 (1) 심각한 청력 손상이 없고, (2) 뚜렷한 인지, 신경 또는 정서장애를 보이지 않는다고 보고되었고, (3) 영아선별 교육진단검사(DEP; Jang et al., 2008)에서 의사소통 영역을 제외한 전체 영역이 백분위 $35 \% \mathrm{ile}$ 이상으로 정상 발달에 속하며, (4) 한국판 맥아더-베이츠 의사소통발달 평가(K M-B CDI; $\mathrm{Pae} \& \mathrm{Kwak}$, 2011)에서 표현어휘 수가 연령 집단별 평균에서 $10 \%$ ile 미만, (5) 영유아 언어발달검사(SELSI; Kim, Kim, Yoon, \& Kim, 2003)에서 표현언어가 10\%ile 미만이며, (6) 18-23개월에 명료하게 발음하는 단어의 수가 10 개 이하 혹은 24-30개월에 사용하는 단어 의 수가 50 개 미만이거나 단어 조합이 출현하지 않았다(Hong \& Kim, 2005; Paul, 1991; Paul \& Jennings, 1992; Rescorla, 1989; Thal \& Bates, 1988).

일반 아동은 양육자로부터 (1) 출생 및 발달상 문제가 나타나지 않았다고 보고되고, (2) 영아선별 교육진단검사(DEP; Jang et al., 2008)에서 모든 영역이 백분위 $35 \%$ ile 이상으로 정상 발달에 속하 며, (3) 한국판 맥아더-베이츠 의사소통발달 평가(K M-B CDI; Pae \& Kwak, 2011)에서 표현어휘 수가 연령 집단별 평균에서 $10 \%$ ile 이 상, (4) 영유아 언어발달검사(SELSI; Kim et al., 2003)에서 수용 및 표현언어가 $10 \%$ ile 이상인 18-30개월 아동을 대상으로 하였다.

연구 대상자의 배경 정보는 Table 1에 제시하였다. 세 집단의 평 
Table 1. Participants' information

\begin{tabular}{lcc}
\hline & Gender (boy:girl) & Age $(\mathrm{mo})$ \\
\hline CP group $(\mathrm{N}=20)$ & $10: 10$ & $24.00(3.63)$ \\
LT group $(\mathrm{N}=20)$ & $15: 5$ & $23.90(3.93)$ \\
TD group $(\mathrm{N}=20)$ & $9: 11$ & $23.90(3.71)$ \\
Total $(\mathrm{N}=60)$ & $34: 26$ & $23.93(3.70)$ \\
\hline
\end{tabular}

$\mathrm{CP}=$ children with cleft palate; $\mathrm{LT}=$ late talking children; $\mathrm{TD}=$ typically developing children.

균 생활연령을 비교하였을 때 구개열 아동 24.00 개월 $(\mathrm{SD}=3.63)$, 말 늦은 아동 23.90개월 $(\mathrm{SD}=3.93)$, 일반 아동 23.90개월 $(\mathrm{SD}=3.71)$ 이었다. 집단 간 생활연령에 유의미한 차이가 있는지 검증하기 위 해 일원배치 분산분석(one-way ANOVA)을 실시한 결과, 세 집단 의 생활연령 간에 유의미한 차이는 없었다 $\left(F_{(2,57)}=0.005, p=.995\right)$.

\section{자료수집}

연구 절차는 한림대학교 생명윤리위원회의 승인(HIRB-2015064, HIRB-2015-065)을 받아 진행되었다. 자발화 수집은 언어병리 학 전공 대학원생이 대상자의 가정에 방문하여 이루어졌으며, 양육 자와 검사자가 각 20 여분 동안 아동들이 쉽게 접할 수 있는 장난감 (주방놀이, 목욕놀이, 낚시놀이, 자동차, 공, 딸랑이, 책)을 이용해 아동과 상호작용하여 총 40 분간 자발화를 수집하였다. 모든 상호 작용상황은 캠코더(Samsung HMX-H205BD)와음성 녹음기(SONY ICD-PX333)를 통해 녹화 및 녹음되었다.

\section{자료분석}

상호작용 자료는 수집 후 2 주 이내에 영상 및 녹음 자료를 토대로 전사를 진행하였다. 전사는 아동의 목표 형태 및 음성 전사를 함께 기록하였다. 아동의 활발한 상호작용을 관찰하기 위해 상호작용 자료의 전반부 3 분과 후반부 2 분은 제외하였으며, 부모상호작용 15 분, 검사자 상호작용 15 분 자료가 전사되었다. 전사가 완료된 후 에는 녹음 자료를 다시 듣고 음성 전사가 정확하게 이루어졌는지 재확인하였다. 전사 원칙은 Jung, Pae와 Kim (2006)을 참조하여 자 료를 3 번 반복해서 들어도 전사가 불가능한 발성이나 발화는 전사 하지 않았으며, 모방과 자발화를 구분하지 않고 모두 전사하였다. 전사된 자료 중 감탄사나 간투사만으로 이루어진 발화 및 음절성 발성이나 자곤처럼 의미가 분명하지 않은 발화는 분석에서 제외하 였으며, 대답하기 기능으로 산출한 '네, 응, 어'는 첫 번째로 산출된 것만 발화로 포함시켰다. 모든 분석치는 아동이 산출한 발화 중 연 속 50 개 발화를 선정하여 분석하였다. 연속 50 개 발화는 전체 전사 자료에서 아동별 전체 발화 수의 중앙값을 구하여, 중앙값 전후의
발화를 25개씩 택하는 방식으로 선정하였다.

\section{분석치}

구개열 아동, 말 늦은 아동, 일반 아동의 표현어휘에 나타난 음운 특성을 살펴보기 위해 서로 다른 낱말 수, 자음 목록 수, 조음위치 및 조음방법별 자음 산출 비율, 어절 첫 소리 유형, 어절 첫 자음 정 확도를 분석하였다.

\section{서로 다른 낱말수}

아동의 표현어휘 수에 대한 정보는 서로 다른 낱말 수(NDW)로 보았다. 낱말에 대한 분석 기준은 Hardin-Jones와 Chapman (2014) 연구를 참조하여 의사소통 의도를 포함하여 표현한 발화에서 문맥 적으로 적절하고 아동이 산출한 형태가 성인의 목표 형태와 음성 적으로 유사할 때 동일한 낱말로 간주하여 전사하였다. 전사 자료 에서 서로 다른 낱말 수는 한국어 발화 분석기 (Korean Language Analysis, http://kla.hallym.ac.kr/) 프로그램을 이용해 분석하였다.

\section{자음 목록수}

자음 목록은 Stoel-Gammon (1985)의 제안을 토대로 서로 다른 2개 이상의 구어 발화(meaningful speech)에서 산출된 자음만을 포함하였다. 활음이나 보상 조음으로 나타난 성문 파열음은 자음 목록수에 포함하지 않았다.

조음위치 및 조음방법별 자음 산출 비율

모든 산출 비율은 초성과 종성을 구분하지 않고 동일하게 세어 계산하였다. 조음위치별 자음 산출 비율은 (각 위치별 산출된 자음 수/전체 산출된 자음 수) $\times 100$ 으로 계산하였으며, 조음방법별 자 음 산출 비율은 (각 방법별 산출된 자음 수/전체 산출된 자음 수) $\times 100$ 으로 계산하였다.

\section{어절 첫 소리 유형}

아동은 18 개월 이후부터 낱말 조합이 나타나고 문법형태소가 출현하므로 아동의 자발화를 낱말 단위보다 어절 단위로 나누어 보는 것이 적절하다(Ha \& Pi, 2016; Yoon, Kim \& Kim, 2013). 따라 서 어절 단위를 기준으로 첫 소리 특성을 살펴보았다. 어절 선정 기 준은 Yoon 등(2013) 연구를 참조하여 우선적으로 표준어 띄어쓰 기를 기준으로 어절을 구분하였다. 그러나 본용언과 보조용언, 관 형어와 불완전 명사, 부정어와 동사, 수사와 단위가 결합된 경우 두 개의 어절을 하나로 보았다.

어절 첫 소리 유형은 아동이 산출한 발화 중 연속한 50 개 발화의 
음성 전사를 토대로 폐쇄음, 파찰음, 마찰음, 비음, 유음, 활음, 모음, 보상 조음으로 시작하는 어절을 구분하였다. 또한 어절 첫 소리를 장애음 범주와 공명음 범주로 구분하여 보았다. 장애음과 공명음 범주로 구분할 때는 보상 조음으로 시작하는 어절을 제외하였다. 즉, 장애음으로 시작하는 어절은 구강에서 기류의 방해를 받아 산 출되는 폐쇄음, 파찰음, 마찰음으로 시작하는 어절이 포함되었으 며, 공명음으로 시작하는 어절은 구강과 비강을 지나면서 기류의 공명이 일어나는 비음, 유음, 활음, 모음으로 시작하는 어절이 포함 되었다.

어절 첫 자음 정확도

어절 첫 자음 정확도는 아동이 의도한 목표 형태에서 어절 첫 말 소리가 자음인 경우에만 구하였다. 따라서, 목표 형태가 모음인 경 우는 계산에서 제외하였으며 (정확하게 산출한 어절 첫 자음 개수/ 전체 어절 첫 자음 개수 $) \times 100$ 으로 구하였다. 이때 철자 표기법과 는 다르나 음성 언어에서 경음화가 허용되는 어절의 경우 첫 자음 을 정확하게 산출하였다고 판단하였다(예: 아동이 /바나나/를 [바 나나]가 아닌 [빠나나]로 산출하여도 어절 첫 자음을 정확하게 산 출하였다고 분석하였다).

\section{신뢰도}

자료의 전사 신뢰도와 측정치의 분석 신뢰도를 위해 전체 자료 의 $20 \%$ 를 임의로 선정하여 전사자 간 신뢰도 및 분석자 간 신뢰도 를 구하였다. 전사자 간 신뢰도와 분석자 간 신뢰도 모두 언어병리 학 전공 대학원생이 분석하였다. 신뢰도를 구하기 전, 분석자에게 전사 방법과 분석 방법에 대해 설명한 후 본 실험에 포함되지 않은 자료를 이용해 1 시간씩 3 회 동안 전사 및 분석 과정을 연습하였다. 전사 신뢰도는 전체 음성 전사 자료에서 (일치한 자음 수)/(전체 자 음 수) $\times 100$ 으로 계산하였다. 그 결과 전사자 간 신뢰도는 $83.65 \%$ 로 나타났다. 분석자 간 신뢰도는 측정치 값을 계산한 것을 토대로 Cohen's Kappa를 이용하여 측정하였다. 그 결과, 어절 첫 말소리 유 형은 .982 , 어절 첫 자음 정확도는 .918으로 높은 분석자 간 신뢰도 가 나타났다.

Table 2. The number of different words (NDW)

\begin{tabular}{ll}
\hline & \multicolumn{1}{c}{ NDW } \\
\hline CP group $(\mathrm{N}=20)$ & $27.60(11.62)$ \\
LT group $(\mathrm{N}=20)$ & $15.90(7.02)$ \\
TD group $(\mathrm{N}=20)$ & $37.65(12.96)$ \\
\hline
\end{tabular}

Values are presented as mean (SD).

$\mathrm{CP}=$ children with cleft palate; $\mathrm{LT}=$ late talking children; $\mathrm{TD}$ = typically developing children.

\section{통계 분석}

통계 처리는 SPSS 22.0 프로그램을 사용하였다. 자발화에서 수 집된 측정치가 집단 간 차이를 나타내는지 살펴보기 위해 일원분 산분석(one-way ANOVA)을 실시하였다. 이후사후분석은 Scheffe 검정을 실시하였으며 모든 유의 수준은 $p<.05$ 로 설정하였다.

\section{연구결과}

\section{서로 다른 낱말 수}

구개열 아동, 말 늦은 아동, 일반 아동의 50 발화에서 수집된 서로 다른 낱말 수는 Table 2에 제시하였다. 서로 다른 낱말 수는 구개열 아동이 27.60개, 말 늦은 아동이 15.90 개, 일반 아동이 37.65 개로 나 타났다. 서로 다른 낱말 수를 비교한 결과, 집단 간 유의미한차이가 나타났다 $\left(F_{(2,57)}=20.176, p<.001\right)$. 사후 분석 결과, 구개열 아동과 말 늦은 아동 $(p=.005)$, 구개열 아동과 일반 아동 $(p=.018)$, 말 늦은 아동과 일반 아동 $(p<.001)$ 간에 유의한 차이가 나타났다.

\section{자음 목록 수}

구개열 아동, 말 늦은 아동, 일반 아동의 자음 목록 수 및 집단별 $70 \%$ 이상의 대상자에게 포함된 자음 목록을 Tables 3 , 4 에 제시하 였다. 초성 자음 목록수는 구개열 아동 5.55개, 말 늦은 아동 6.10개,

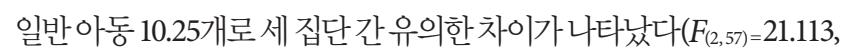
$p<.001)$. 사후 분석 결과, 구개열 아동과 일반 아동 $(p<.001)$, 말 늦 은 아동과 일반 아동 $(p<.001)$ 사이에서 유의한 차이가 나타났다.

종성 자음 목록 수는 구개열 아동 2.35 개, 말 늦은 아동 1.35 개,

Table 3. The number of consonant inventory

\begin{tabular}{lrcr}
\hline & \multicolumn{1}{c}{ Initial } & Final & \multicolumn{1}{c}{ Total } \\
\hline CP group (N=20) & $5.55(3.22)$ & $2.35(0.93)$ & $6.55(3.36)$ \\
LT group (N=20) & $6.10(1.29)$ & $1.35(1.09)$ & $6.65(1.50)$ \\
TD group (N=20) & $10.25(2.59)$ & $2.40(1.14)$ & $11.10(2.75)$ \\
\hline
\end{tabular}

Values are presented as mean (SD).

$\mathrm{CP}=$ children with cleft palate; $\mathrm{LT}=$ late talking children; $\mathrm{TD}=$ typically developing children.

Table 4. Phones in consonant inventories of $70 \%$ of subjects

\begin{tabular}{lccc}
\hline & Initial & Final & Total \\
\hline CP group & $m, n$ & $m$ & $m, n$ \\
LT group & $p^{*}, t^{*}, m$ & - & $p^{*}, t^{*}, m$ \\
TD group & $t, k, t^{*}, t c, m, n$ & $n, y$ & $t, k, t^{*}, t c, m, n, y$ \\
\hline
\end{tabular}

$\mathrm{CP}=$ children with cleft palate; $\mathrm{LT}=$ late talking children; $\mathrm{TD}=$ typically developing children. 
일반아동 2.40 개로 세 집단간 유의한차이가 나타났다 $\left(F_{(2,57)}=6.259\right.$, $p=.003)$. 사후 분석 결과, 구개열 아동과 말 늦은 아동 $(p=.016)$, 말 늦은 아동과 일반 아동 $(p=.011)$ 간에 유의한 차이를 보였다.

전체 자음 목록 수는 구개열 아동 6.55 개, 말 늦은 아동 6.65 개, 일반 아동 11.10 개로 세 집단 간 유의한 차이가 나타났다 $\left(F_{(2,57)}=\right.$ $19.182, p<.001)$. 사후 분석 결과, 구개열 아동과 일반 아동 $(p<.001)$, 말 늦은 아동과 일반 아동 $(p<.001)$ 간에 유의한 차이가 나타났다.

집단별 70\% 이상(14명 이상) 아동이 산출한 자음 목록을 보면, 구개열 아동은 비음인 /ㅁ, ㄴ/를 주로 산출하였으며 말 늦은 아동 은 초성 /ㅃ, ㄸ, ㅁ/만을 산출하였다. 일반 아동은/ᄃ, ᄀ, 匹, ㅈ, ㅁ, ㄴ, 이을 산출하였다.

\section{조음위치 및 조음방법별 자음 산출 비율}

\section{조음위치별 자음 산출 비율}

구개열 아동, 말 늦은 아동, 일반 아동의 조음위치별 자음 산출 비율은 Table 5에 제시하였다. 조음위치별 자음 산출 비율을 살펴 보면 일반 아동은 치경음, 연구개음, 양순음, 경구개음, 성문음 순서 의 자음 산출 비율을 보였다. 반면에 구개열 아동은 양순음, 치경 음, 연구개음, 성문음, 경구개음 순서로 자음을 산출하였으며, 말 늦 은 아동은 양순음, 치경음, 연구개음, 경구개음, 성문음 순서로 자 음을 산출하였다.

조음위치별 자음 산출 비율을 비교한 결과, 양순음 산출 비율 $\left(F_{(2,57)}=7.207, p=.002\right)$ 과 경구개음 산출 비율 $\left(F_{(2,57)}=6.805, p=.002\right)$ 에서 집단 간 유의한 차이가 나타났다. 사후 분석 결과, 양순음 산 출 비율은 구개열 아동과 일반 아동 $(p=.003)$, 말 늦은 아동과 일반 아동 $(p=.022)$ 간에 유의한 차이가 나타났다. 양순음 산출에 대한
특성을 면밀히 비교하고자 양순음을 조음방법별로 구분하여 양순 폐쇄음과 양순 비음의 산출 비율을 살펴보았다. 독립표본 $t$-검정 $(t$ test)을 실시한 결과, 구개열 아동과 말 늦은 아동의 양순음 산출 비 율 중양순 폐쇄음과양순 비음간 유의한차이가 나타났다 $(t=4.035$, $p<.001)$. 양순 폐쇄음 산출 비율은 구개열 아동 $23.61 \%(\mathrm{SD}=26.09)$, 말 늦은 아동 $52.96 \%(\mathrm{SD}=19.44)$ 로 말 늦은 아동의 양순 폐쇄음 산출 비율이 유의하게 높았으며, 양순 비음 산출 비율은 구개열 아 동 76.39\% ( $\mathrm{SD}=26.09)$, 말 늦은 아동 $47.04 \%(\mathrm{SD}=19.44)$ 로 구개 열 아동에게서 유의하게 높았다. 경구개음 산출 비율은 구개열 아 동과 말 늦은 아동 $(p=.019)$, 구개열 아동과 일반 아동 $(p=.005)$ 에 서 유의한차이가 나타났다.

\section{조음방법별 자음 산출 비율}

구개열 아동, 말 늦은 아동, 일반 아동의 조음방법별 자음 산출 비율은 Table 6에 제시하였다. 조음방법별 자음 산출 비율을 살펴 보면 일반 아동과 말 늦은 아동은 폐쇄음, 비음, 파찰음, 마찰음, 유 음 순서의 자음 산출 비율을 보였다. 반면에 구개열 아동은 비음, 폐 쇄음, 유음, 마찰음, 파찰음 순서로 자음을 산출하였다.

조음방법별 자음 산출 비율을 비교한 결과, 폐쇄음 산출 비율 $\left(F_{(2,57)}=4.058, p=.023\right)$, 파찰음 산출 비율 $\left(F_{(2,57)}=6.805, p=.002\right)$, 비음 산출 비율 $\left(F_{(2,57)}=9.950, p<.001\right)$, 유음 산출 비율 $\left(F_{(2,57)}=6.908\right.$, $p=.002)$ 에서 집단 간 유의한 차이가 나타났다. 사후 분석 결과, 폐 쇄음 산출 비율은 구개열 아동과 말 늦은 아동( $p=.039)$, 파찰음 산 출 비율은 구개열 아동과 말 늦은 아동 $(p=.019)$, 구개열 아동과 일 반 아동 $(p=.005)$ 간에 유의한 차이가 나타났다. 비음 산출 비율은 구개열 아동과 말 늦은 아동 $(p=.005)$, 구개열 아동과 일반 아동

Table 5. Consonant frequency (\%) by place of articulation

\begin{tabular}{llcccc}
\hline Group & Labial & Alveolar & Palatal & Velar & Glottal \\
\hline CP group $(\mathrm{N}=20)$ & $40.18(17.73)$ & $33.27(15.35)$ & $1.78(3.71)$ & $22.18(17.19)$ & $2.59(2.14)$ \\
LT group $(\mathrm{N}=20)$ & $36.36(20.49)$ & $31.27(15.19)$ & $9.94(11.88)$ & $20.31(10.78)$ & $2.12(3.47)$ \\
TD group $(\mathrm{N}=20)$ & $21.56(8.43)$ & $36.68(9.03)$ & $11.31(8.89)$ & $27.75(9.68)$ & $2.70(3.24)$ \\
\hline
\end{tabular}

Values are presented as mean (SD).

$\mathrm{CP}=$ children with cleft palate; $\mathrm{LT}$ = late talking children; $\mathrm{TD}$ = typically developing children.

Table 6. Consonant frequency (\%) by manner of articulation

\begin{tabular}{lccccc}
\hline & Stops & Affricates & Fricatives & Nasals & Liquids \\
\hline CP group $(\mathrm{N}=20)$ & $38.13(24.31)$ & $1.78(3.71)$ & $2.97(2.17)$ & $53.26(24.77)$ & $3.85(3.58)$ \\
LT group ( $\mathrm{N}=20)$ & $53.18(16.03)$ & $9.94(11.88)$ & $2.56(3.86)$ & $33.78(16.46)$ & $0.54(0.99)$ \\
TD group ( $\mathrm{N}=20)$ & $51.14(11.73)$ & $11.31(8.89)$ & $4.56(4.36)$ & $29.67(8.58)$ & $3.32(3.69)$ \\
\hline
\end{tabular}

Values are presented as mean (SD).

$\mathrm{CP}=$ children with cleft palate; $\mathrm{LT}=$ late talking children; $\mathrm{TD}$ = typically developing children. 
$(p<.001)$ 간에 유의한 차이가 나타났다. 유음 산출 비율은 구개열 아동과 말 늦은 아동 $(p=.004)$, 말 늦은 아동과 일반 아동 $(p=.020)$ 간에 유의한 차이가 나타났다.

구개열 아동, 말 늦은 아동, 일반 아동의 장애음과 공명음의 산출 비율은 Table 7에 제시하였다. 장애음 산출 비율은 구개열 아동 $42.89 \%$, 말 늦은 아동 $65.68 \%$, 일반 아동 $67.01 \%$ 였으며, 공명음 산 출 비율은 구개열 아동 $57.11 \%$, 말 늦은 아동 $34.32 \%$, 일반 아동 $32.99 \%$ 로 나타났다. 장애음과 공명음 산출 비율은 집단 간 유의한 차이를 보였다 $\left(F_{(2,57)}=10.612, p<.001\right)$. 사후 분석 결과, 구개열 아 동이 다른 두 집단에 비해 장애음 산출 비율은 유의하게 낮았고 ( $p=.001)$, 공명음 산출 비율은 유의하게 높았다 $(p=.001)$. 말 늦은 아동과 일반 아동 간에는 장애음과 공명음 산출 비율에 대해 유의 미한 차이가 나타나지 않았다.

\section{어절 첫 소리 유형}

구개열 아동, 말 늦은 아동, 일반 아동의 어절 첫 소리 유형을 장 애음과 공명음 범주로 구분하여 살펴본 결과는 Table 8에 제시하였 다. 장애음으로 시작하는 어절은 구개열 아동 $24.94 \%$, 말 늦은 아

Table 7. Frequency (\%) of obstruents and sonorants

\begin{tabular}{lcc}
\hline & Obstruents & \multicolumn{1}{c}{ Sonorants } \\
\hline CP group $(\mathrm{N}=20)$ & $42.89(26.02)$ & $57.11(26.02)$ \\
LT group $(\mathrm{N}=20)$ & $65.68(16.63)$ & $34.32(16.63)$ \\
TD group $(\mathrm{N}=20)$ & $67.01(9.27)$ & $32.99(9.27)$ \\
\hline
\end{tabular}

Values are presented as mean (SD).

$\mathrm{CP}=$ children with cleft palate; $\mathrm{LT}=$ late talking children; $\mathrm{TD}$ = typically developing children.

Table 8. Frequency $(\%)$ of eojoel beginning with obstruents and sonorants

\begin{tabular}{lcc}
\hline & Obstruents & Sonorants \\
\hline CP group ( $N=20)$ & $24.94(16.05)$ & $63.96(14.83)$ \\
LT group $(\mathrm{N}=20)$ & $46.10(23.51)$ & $53.90(23.51)$ \\
TD group $(\mathrm{N}=20)$ & $47.90(15.49)$ & $52.10(15.49)$ \\
\hline
\end{tabular}

Values are presented as mean (SD).

$\mathrm{CP}=$ children with cleft palate; $\mathrm{LT}=$ late talking children; $\mathrm{TD}=$ typically developing children.
동 $46.10 \%$, 일반 아동 $47.90 \%$ 로 세 집단 간 유의미한 차이가 있었 다 $\left(F_{(2,57)}=9.310, p<.001\right)$. 사후 분석 결과, 구개열 아동과 말 늦은 아동 $(p=.003)$, 구개열 아동과 일반 아동 $(p=.001)$ 간에 유의한 차이 를 보였다. 공명음으로 시작하는 어절은 구개열 아동 $63.96 \%$, 말 늦 은 아동 $53.90 \%$, 일반 아동 $52.10 \%$ 로 세 집단 간 유의미한차이는 나 타나지 않았다. 구개열 아동의 경우 보상조음으로 시작하는 어절이 $11.10 \%$ 로 나타났는데 이는 장애음과 공명음 범주에서 제외되었다.

장애음과 공명음으로 시작하는 어절 첫 소리 유형을 다섯 가지 조음방법과 모음, 보상 조음으로 구분하여 살펴본 결과는 Table 9 에 제시하였다. 일반 아동과 말 늦은 아동은 모음, 폐쇄음, 비음, 파 찰음, 마찰음, 유음으로 시작하는 어절 순으로 높은 출현율을 보였 으며 보상 조음으로 시작하는 어절은 나타나지 않았다. 구개열 아 동은 모음, 폐쇄음, 비음, 보상 조음, 마찰음, 파찰음, 유음으로 시작 하는 어절 순으로 출현하였다.

세 집단 간 어절 첫 소리 유형에 차이가 있는지 비교한 결과, 폐쇄 음으로 시작하는 어절 $\left(F_{(2,57)}=4.834, p=.012\right)$, 파찰음으로 시작하 는 어절 $\left(F_{(2,57)}=4.062, p=.022\right)$, 마찰음으로 시작하는 어절 $\left(F_{(2,57)}=\right.$ $4.493, p=.015)$, 비음으로 시작하는 어절 $\left(F_{(2,57)}=3.906, p=.026\right)$, 보 상 조음으로 시작하는 어절 $\left(F_{(2,57)}=13.720, p<.001\right)$ 에서 유의한 차 이가 나타났다. 사후 분석 결과, 폐쇄음으로 시작하는 어절은 구개 열 아동이 말 늦은 아동에 비해 유의하게 적었으며 $(p=.005)$, 비음 으로 시작하는 어절은 유의하게 많았다 $(p=.029)$. 파찰음 시작하 는 어절 $(p=.032)$ 과 마찰음으로 시작하는 어절 $(p=.027)$ 은 구개열 아동이 일반 아동에 비해 유의하게 적었다. 보상 조음으로 시작하 는 어절은 구개열 아동에게서만 나타났으므로 나머지 두 집단에 비해 유의하게 높은 비율을 보였다 $(p<.001)$.

Table 10. Consonants correct (\%) of the initial consonants of eojeols

\begin{tabular}{lc}
\hline & Consonants correct \\
\hline CP group ( $N=20)$ & $54.22(20.06)$ \\
LT group $(\mathrm{N}=20)$ & $69.30(21.25)$ \\
TD group $(\mathrm{N}=20)$ & $77.71(13.03)$ \\
\hline
\end{tabular}

Values are presented as mean (SD).

$\mathrm{CP}=$ children with cleft palate; $\mathrm{LT}=$ late talking children; $\mathrm{TD}=$ typically developing children.

Table 9. The ratio of eojoel beginning with consonant types by manner of articulation

\begin{tabular}{|c|c|c|c|c|c|c|c|}
\hline & Stops & Affricates & Fricatives & Nasals & Liquids & Vowels & Compensatory articulation \\
\hline $\mathrm{CP}$ group $(\mathrm{N}=20)$ & $21.07(14.30)$ & $1.38(3.69)$ & $2.48(1.76)$ & $18.82(10.02)$ & $0.15(0.46)$ & $41.99(14.60)$ & $11.10(13.40)$ \\
\hline LT group $(\mathrm{N}=20)$ & $36.00(20.91)$ & $6.90(10.42)$ & $3.21(6.13)$ & $9.85(9.42)$ & $0.00(0.00)$ & $42.52(18.58)$ & $0.00(0.00)$ \\
\hline TD group $(\mathrm{N}=20)$ & $31.89(9.82)$ & $8.44(9.00)$ & $7.56(7.76)$ & $15.72(11.37)$ & $0.23(0.57)$ & 34.32 (12.59) & $0.00(0.00)$ \\
\hline
\end{tabular}

Values are presented as mean (SD).

$\mathrm{CP}=$ children with cleft palate; $\mathrm{LT}$ = late talking children; $\mathrm{TD}$ = typically developing children. 


\section{어절 첫 자음 정확도}

구개열 아동, 말 늦은 아동, 일반 아동의 어절 첫 자음 정확도는 Table 10에 제시하였다. 어절 첫 자음 정확도는 구개열 아동 $54.22 \%$, 말 늦은 아동 $69.30 \%$, 일반 아동은 $77.71 \%$ 로 나타났다. 어절 첫 자음 정확도를 비교한 결과, 집단 간 유의미한 차이가 나타났다 $\left(F_{(2,57)}=\right.$ $8.300, p=.001)$. 사후 분석 결과, 구개열 아동이 말 늦은 아동 $(p=$ $.043)$ 이나 일반 아동 $(p=.001)$ 에 비해 어절 첫 자음 정확도가 낮았 다. 말 늦은 아동은 일반 아동에 비해서 어절 첫 자음 정확도가 낮 았으나 통계적으로는 유의하지 않았다.

\section{논의 및 결론}

본 연구는 18-30개월 구개열 아동, 말 늦은 아동, 일반 아동의 상 호작용에 나타난 연속 50 개 발화를 바탕으로 서로 다른 낱말 수, 자음 목록 수, 조음위치 및 조음방법별 자음 산출 비율, 어절 첫 소 리 유형, 어절 첫 자음 정확도를 살펴보았다. 먼저, 표현어휘량과 밀 접한 관련이 있는 서로 다른 낱말 수(NDW)를 비교하였다. 서로 다 른 낱말 수는 일반 아동, 구개열 아동, 말 늦은 아동 순으로 출현하 였으며, 일반 아동이 다른 두 집단에 비해 서로 다른 낱말 수가 많 았다. 또한 구개열 아동이 말 늦은 아동에 비해 서로 다른 낱말 수 가 많았다. 이는 말 늦은 아동과 구개열 아동이 또래에 비해 표현어 휘 면에서 제한된 발달을 보인다는 선행 연구와 일치하는 연구 결 과를 제시함과 동시에(Ha, 2014; Hardin-Jones \& Chapman, 2014; Paul, 1991; Sim \& Ha, 2014), 말 늦은 아동의 어휘량이 구개열 아동 에 비해 상대적으로 부족하다는 점을 보여주었다.

자음 목록 수를 비교한 결과, 초성, 종성, 전체 자음 목록 수 모두 에서 집단 간 유의한 차이가 나타났다. 전체 자음의 경우 일반 아동 에 비해 말 늦은 아동과 구개열 아동의 자음 목록 수가 적었으나 말 늦은 아동과 구개열 아동 간의 차이는 보이지 않았다. 집단별 $70 \%$ 이상 아동이 산출한 전체 자음을 자세히 살펴보면 일반 아동은 /ᄃ, ᄀ, 匹, ㅈ, ㅁ, ᄂ, 이, 말 늦은 아동은/뻐, , ㅁ/, 구개열 아동 은/ㅁ, ㄴ/로 나타났다. 구개열 아동 20 명 중 11 명이 구강 압력이 필 요한 폐쇄음, 파찰음, 마찰음을 보상 조음으로 대치하여 산출해서, 대다수 구개열 아동이 공통적으로 산출하는 자음 목록에 비음만 포함되었다. 말 늦은 아동과 구개열 아동은 공통적으로 초기 음운 발달 단계에 산출되는 비음과 일부 폐쇄음만을 안정적으로 산출 하였다. 자음 목록 수와 산출 유형에 대한 결과는 구개열 아동과 말 늦은 아동이 지연된 음운 발달로 인해 자음 목록 수가 적고, 산출 유형에서 지연된 양상을 보인다는 선행연구와 일치한다(Chapman et al., 2001; Moon \& Ha, 2012; Rescorla \& Ratner, 1996; Sim \& Ha,
2014). 자음 목록을 초성과 종성으로 나누어 자세히 살펴보면, 일 반 아동의 초성은 /ᄃ, ᄀ, 匹, ㅈ, ㅁ, ㄴ/, 말 늦은 아동은 /빠, , ㅁ/, 구개열 아동은 /ㅁ, ㄴ/로 나타나 일반 아동은 폐쇄음, 파찰음, 비음으로 이루어진 초성 자음 목록이 나타난 반면, 다른 두 집단은 초성 자음 산출이 제한되었다. 종성 자음을 살펴보면 일반 아동은 /ㄴ, 익ㄱㄱ개열 아동은/미로 나타났고 말 늦은 아동은 초성 자음 목록에 비음이 포함되었지만 종성이 출현하지 않았다. 즉, 말 늦은 아동의 음운 지연은 자음 목록뿐 아니라 종성과 관련된 음절 구조 면에서도 제한을 보였다는 점을 알 수 있다. 반면에 구개열 아동은 비음 종성이 나타나 음절 구조 면에서는 일반 아동과 다르지 않았 다는 점을 시사한다. 한국어에서 종성은 생후 15 개월 경 비음 종성 부터 안정적으로 출현하기 시작하는 점을 고려하면(Park \& $\mathrm{Ha}$, 2016), 18-30개월 사이의 말 늦은 아동에게서 종성이 출현하지 않 은 것은 음운 발달 지연을 보인다고 제안할 수 있는 근거이다.

조음위치별 자음 산출 비율을 살펴보면, 본 연구에서 일반 아동 은 치경음, 연구개음, 양순음, 경구개음, 성문음 순서로 높은 산출 비율을 보였는데 이는 선행연구 결과와 일치한다 $(\mathrm{Ha} \& \mathrm{Pi}, 2016$; Shin, 2005). 조음위치별 자음 산출 비율을 비교한 결과, 양순음과 경구개음 비율에서 집단 간 차이가 나타났다. 양순음 산출 비율을 먼저 보면, 구개열 아동과 말 늦은 아동의 양순음 산출 비율은 일반 아동에 비해 유의하게 높았다. 양순음 산출 특성을 자세히 살펴보 면, 양순 폐쇄음은 구개열 아동보다 말 늦은 아동의 산출 비율이 유 의하게 높았고, 양순 비음 산출 비율은 구개열 아동이 말 늦은 아동 에 비해 유의하게 높았다. 즉, 말 늦은 아동은 치조음과 경구개음 등 의 습득 지연으로 인해 어린 연령대에서 주로 산출되는 구강 앞쪽 소리를 여전히 많이 산출하지만 일반 아동과 유사하게 장애음을 주로 산출하였다. 반면, 구개열 아동은 구강 압력을 형성하지 않아 도 쉽게 산출할 수 있는 양순 비음을 주로 산출하였다(Chapman et al., 2001; Moon \& Ha, 2012). 집단별 자음 목록과 조음위치별 산출 비율에 대한 결과를 종합해보았을 때, 말 늦은 아동과 구개열 아동 모두 자음 목록에 치경음, 연구개 폐쇄음, 경구개음이 포함되지 않 았다. 따라서, 자신의 자음 목록에 없는 음소로 이루어진 어휘를 산 출하기 위해 자신이 산출할 수 있는 양순 폐쇄음, 양순 비음, 혹은 보상조음으로 대치하여 산출하였다. 경구개음 산출 비율은 일반 아동, 말 늦은 아동, 구개열 아동 순으로 나타났으며, 구개열 아동이 다른 두 집단에 비해 유의하게 낮은 비율을 보였다. 이는 구개열 아 동이상호작용상황에서 경구개음이 포함될 수 있는 어휘는 빈번하 게 산출하였으나(예: 저기, 자동차 등) 경구개음을 보상조음으로 대 치하였기 때문에 다른 집단에 비해 낮은 산출 비율이 나타난 것으 로 해석할 수 있다. 
조음방법별 자음 산출 비율을 살펴보면, 본 연구에서 일반 아동 은 폐쇄음, 비음, 파찰음, 마찰음, 유음 순으로 높은 산출 비율을 보 였는데, 이는 18-30개월 한국 아동을 대상으로 말소리 빈도를 살펴 본 선행 연구 결과와 일치한다( $\mathrm{Ha} \& \mathrm{Pi}, 2016)$. 조음방법별 자음 산 출 비율을 비교한 결과, 폐쇄음, 파찰음, 비음, 유음 비율에서 집단 간 차이가 나타났다. 폐쇄음과 파찰음의 산출 비율은 구개열 아동 이 다른 두 집단에 비해 유의하게 낮았던 반면에 비음 산출 비율은 높았다. 이는 구개열 아동에게서 폐쇄음 산출이 제한적이며 비음 을 주로 사용한다는 기존 연구를 지지하는 결과이다(Chapman, 1991; Moon \& Ha, 2012). 유음의 산출 비율은 일반 아동과 구개열 아동이 말 늦은 아동에 비해 유의하게 높았다. 유음의 습득 연령은 2세 이후이므로(Kim \& Pae, 2005) 음운 발달이 지연된 말 늦은 아 동에게 유음 산출의 어려움이 있을 수 있다. 반면에 구개열 아동은 공명음 산출에 어려움을 보이지 않는다. 즉, 구개열 아동은 월령이 증가하면서 조사와 어미에 나타나는 /리를 일반 아동과 유사하게 정조음하였다고 볼수 있다.

조음방법별 자음 산출 비율을 장애음과 공명음 범주로 분류해 서 살펴보았다. 본 연구에서 일반 아동은 장애음을 $67.01 \%$, 공명음 을 $32.99 \%$ 산출하였다. 이는 $18-30$ 개월 일반 아동을 대상으로 이루 어진 선행연구에 제시된 장애음 비율 $61.65 \%$, 공명음 비율 $38.35 \%$ 와도 유사한 결과이다( $\mathrm{Ha} \& \mathrm{Pi}, 2016)$. 집단 간 차이를 살펴보면, 구 개열 아동이 다른 두 집단에 비해 공명음 산출 비율이 유의하게 높 은 반면, 장애음 산출 비율은 낮았다. 말 늦은 아동과 일반 아동은 공명음과 장애음 산출 비율에 차이가 나타나지 않았다. 말 늦은 아 동은 제한된 수의 자음 목록을 보이기는 하나 음소의 공명 자질 여 부에 따라 영향 받지 않고 한국어 초기 어휘의 일반적인 음소 빈도 를 보인다. 반면에 구개열 아동은 수술 이후에도 보상 조음과 같이 잘못 학습된 조음 패턴이나 연인두 기능 부전으로 인해 제한적인 장애음 산출을 보이면서 장애음이 생략되거나 공명음으로 대치되 어 공명음의 산출 빈도가 높게 나타났다고 할 수 있다.

어절 첫 소리 유형을 장애음과 공명음 범주로 먼저 살펴보면, 본 연구에서 일반 아동은 장애음으로 시작하는 어절 비율(47.90\%)보 다 공명음으로 시작하는 어절 비율(52.10\%)이 높게 나타났다. 이러 한 결과는 18-30개월 한국 아동에게서 장애음으로 시작하는 어절 비율(44.59\%)보다 공명음으로 시작하는 어절 비율(55.41\%)이 높다 는 선행연구와 일치하였다( $\mathrm{Ha} \& \mathrm{Pi}, 2016)$. 장애음과 공명음으로 시작하는 어절 비율을 비교한 결과, 장애음으로 시작하는 어절은 구개열 아동이 말 늦은 아동이나 일반 아동에 비해 유의하게 낮았 고, 공명음으로 시작하는 어절은 세 집단 간 차이가 없었다. 구개열 아동이 다른 두 집단에 비해 장애음으로 시작하는 어절 비율이 낮
은 이유는 구강 압력을 요하는 진자음 산출에 제한을 보인다는 국 내외 연구 결과와 일치한다(Estrem \& Broen, 1989; Ha, 2014; Hardin-Jones \& Chapman, 2014).

어절 첫 소리 유형을 다섯 가지 조음방법과 모음, 보상 조음으로 나누어 자세히 살펴보면, 본 연구에서 일반 아동은 모음(34.32\%), 폐쇄음(31.89\%), 비음(15.72\%), 파찰음(8.44\%), 마찰음(7.56\%), 유 음 $(0.23 \%)$ 으로 시작하는 어절 순으로 높은 산출 비율을 보였다. 이 는 18-30개월 한국 아동에게서 모음(35.22\%), 폐쇄음(32.14\%), 비 음(20.06\%), 파찰음(6.70\%), 마찰음(5.75\%), 유음( $0.14 \%)$ 으로 시작 하는 어절 비율을 제시한 것과 유사한 결과이다( $\mathrm{Ha} \& \mathrm{Pi}, 2016)$. 어 절 첫 소리 유형을 비교한 결과, 폐쇄음, 파찰음, 마찰음, 비음, 보상 조음으로 시작하는 어절에서 집단 간 차이가 나타났다. 세 아동 모 두 모음, 폐쇄음, 비음으로 시작하는 어절 순으로 높은 산출 비율이 나타났지만, 말 늦은 아동에 비해 구개열 아동이 폐쇄음으로 시작 하는 어절 비율은 낮고 비음으로 시작하는 어절 비율은 높았다. 통 계적으로 유의하지는 않았으나 일반 아동에 비해 구개열 아동이 폐쇄음으로 시작하는 어절 비율은 낮고 비음으로 시작하는 어절 비율이 높았다. 또한 파찰음과 마찰음으로 시작하는 어절 비율은 구개열 아동에 비해 일반 아동이 유의하게 높았다. 보상조음으로 시작하는 어절은 구개열 아동에게서 $11.10 \%$ 로 나타났는데, 폐쇄 음, 파찰음, 마찰음을 대치하여 사용하는 형태로 출현하였다. 따라 서 구개열 아동은 어절 첫 소리에서도 구강 압력이 덜 요구되는 비 음을 선호하며 폐쇄음, 파찰음, 마찰음은 생략하거나 공명음이나 보상조음으로 대치하고, 장애음으로 시작하는 어휘는 기피하여 산 출하지 않은 것으로 해석할 수 있다.

어절 첫 자음 정확도를 살펴보면, 본 연구에서 일반 아동은 어절 첫 자음 정확도가 $77.71 \%$ 로 나타나 18 -30개월 한국 아동에게서 어 절 첫 자음 정확도가 $83.03 \%$ 로 보고된 것에 비해 다소 낮은 정확도 가 나타났다( $\mathrm{Ha} \& \mathrm{Pi}, 2016) . \mathrm{Ha}$ 와 $\mathrm{Pi}$ (2016)의 연구에서는 18-30개 월 아동을 월령에 따라 두 집단으로 나누었다. 이때, 18-24개월 집 단의 어절 첫 자음 정확도는 $77.65 \%, 25-30$ 개월 집단의 어절 첫 자 음 정확도는 $88.46 \%$ 로 높은 월령대의 아동에게서 어절 첫 자음 정 확도가 유의하게 높았다. 또한 월령 집단별 분석에 포함된 발화 수 에 차이가 있었는데 18-24개월 집단의 발화 수는 2,573개, 25-30개 월 집단의 분석 발화는 3,049 개로 발화 수를 통제하지 않고 모든 구어 발화를 분석하였다. 하지만 본 연구에서는 18-30개월 아동의 분석 발화 수를 연속 50 개 발화로 제한하였으므로 $\mathrm{Ha}$ 와 $\mathrm{Pi}$ (2016) 가 제시한 어절 첫 자음 정확도에 비해 낮은 수치가 나왔다는 것을 추측할 수 있다. 집단별 어절 첫 자음 정확도를 비교한 결과, 구개열 아동은 $54.22 \%$, 말 늦은 아동은 $69.30 \%$, 일반 아동은 $77.71 \%$ 로 나 
타났다. 구개열 아동이 다른 두 집단에 비해 어절 첫 자음 정확도가 낮았으나 말 늦은 아동은 일반 아동과 통계적으로 차이가 없었다. 이 결과는 일반 아동에게서 $71.2 \%$, 구개열 아동에게서 $53.6 \%$ 로 낱 말 첫 자음 정확도가 보고된 선행연구와 매우 유사한 결과라고 볼 수 있다(Estrem \& Broen, 1989). 구개열 아동에게서 어절 첫 자음 정확도가 가장 낮은 이유는 장애음으로 시작하는 어절에서 보상 조음으로의 대치가 빈번했기 때문이다.

본 연구는 18-30개월 구개열 아동, 말 늦은 아동, 일반 아동의 자 발화를 통해 음운 발달 측면을 면밀히 살펴보았다. 연구 결과를 종 합적으로 살펴보면, 말 늦은 아동은 구개열 아동에 비해서도 어휘 발달 면에서 지연되었다. 말 늦은 아동은 음운 발달 면에서 제한된 자음 목록 및 종성이 출현하지 않는 음절 구조의 제약이 있었으며, 초기 음운 발달 시기에 주로 나타나는 양순 폐쇄음의 출현 비율이 높았고, 월령이 증가하면서 습득하는 유음의 출현 비율이 낮았다. 하지만 어절 첫 소리 유형이나 어절 첫 자음 정확도는 일반 아동과 차이를 보이지 않았다. 이러한 사실로 미루어 보아 말 늦은 아동은 표현어휘의 제약과 함께 제한된 자음 목록과 음절 구조를 보이나 자음 정확도는 또래와 유사하다는 점을 알 수 있다. 이는 Storkel과 Morrisette (2002)가 제안한 어휘와 음운의 양방향적 관계가 강조 되는 부분으로 말 늦은 아동의 어휘 목록이 적어 자음 목록의 제약 이 나타났을 수 있고, 반대로 제한된 자음 목록으로 인해 다양한 어휘를 산출하는데 한계가 있을 수 있다고 추측할 수 있다. 말 늦은 아동의 약점은 어휘와 음소 목록의 제약이지만 강점은 자음 정확 도 측면으로, 구개열 아동보다 우수하고 일반 아동과 비슷한 수행 력을 보이는 것으로 나타났다. 이는 말 늦은 아동의 자음 목록수가 적지만 음소가 자음 목록에 포함된 후에는 비교적 안정적으로 산 출한다는 점을 반영한다. 따라서 말 늦은 아동의 강약점을 토대로 자음 산출 시 정확도 개선보다는 다양한 조음위치에서 다양한 소 리를 경험하고 산출할 수 있게 해야 할 것이며, 종성을 포함하는 복 잡한 음절 구조에 대한 제약을 보일 수 있으므로 음절 구조 확장 및 음소 배열 규칙을 강조하는 중재가 필요하다. 기능적이면서 아 동의 자음 목록과 음절 구조를 확장시킬 수 있는 어휘를 목표어로 두고 어휘와 말소리 모두를 촉진하는 중재를 적용하면 도움이 될 것이다.

구개열 아동은 표현어휘 수가 일반 아동에 비해 적기는 하였으나 말 늦은 아동과 비교해서는 많았다. 구개열 아동은 음운 발달 면에 서 자음 목록 수가 적고, 양순음과 비음, 공명음 범주의 말소리를 주로 사용하였으며 이는 어절 첫 소리 유형에서도 동일하게 나타났 다. 또한 보상 조음으로의 빈번한 대치로 인해 어절 첫 자음 정확도 도 낮게 나타났다. 즉, 구개열 아동 또한 말 늦은 아동과 마찬가지로
어휘와 음운 발달 측면이 지연되었으나, 말 늦은 아동과 달리 구강 압력을 요구하는 자음을 기피하고 말소리 산출상의 정확도가 현저 히 낮다는 특징을 알 수 있다. 따라서, 구개열 아동에게는 보상 조 음 같이 부적절하게 습득된 말소리를 소거한 뒤 입술과 혀 끝의 사 용을 촉진하여 장애음 범주의 음소들을 다양하게 경험해볼 수 있 도록 중재를 진행하는 것이 바람직할 것이다.

본 연구는 장애 기저 요인은 다르지만 초기 어휘와 음운 발달상 에 지연을 보이는 말 늦은 아동과 구개열 아동의 초기 어휘에 나타 난음운 특성을 비교해 봄으로써 음운 평가 및 차별적인 중재에 대 해 시사하는 바가 있다. 말 늦은 아동의 일부는 표현언어 측면에서 지연을 보이다가 3-4세 무렵 또래 수준의 언어 발달 정도를 따라 잡 는다는 보고가 있다(Leonard, 2014). 또한, 2세 경 어휘 및 음운 발 달 측면이 지연된 구개열 아동과 또래와 언어 수준이 비슷하다고 확인된 구개열 아동을 3 세까지 추적한 연구에서(Morris \& Ozanne, 2003), 2세에 지연된 구개열 아동이 또래와 언어 수준이 비슷한 구 개열 아동에 비해 3 세 경 표현언어, 자음 정확도, 자음 목록, 음운 변동의 사용에서 유의하게 지연되었다고 한다. 따라서, 18-30개월 에 말 늦은 아동과 구개열 아동이 보인 음운 발달 특성이 이후 연령 에서 자음 정확도, 자음 변이성, 음운 변동의 사용, 말 명료도 및 표 현언어 지연에 영향을 미치는지 살펴볼 필요가 있다. 따라서 후속 연구에서는 말 늦은 아동과 구개열 아동을 종단적으로 관찰하여 또래 수준에 도달하는 아동과 그렇지 못한 아동의 음운 특성을 비 교해 살펴볼 것을 제안한다.

\section{REFERENCES}

Bates, E., Dale, P. S., \& Thal, D. (1995). Individual differences and their implications for theories of language development. In P. Fletcher \& B. MacWhinney (Eds.), The handbook of child language (pp. 96-151). Oxford: Blackwell.

Chang-Song, Y. K. (2004). Early lexical development of Korean infant: 8-17 Months. Korean Journal of Psychology: General, 23, 77-99.

Chapman, K. L. (1991). Vocalizations of toddlers with cleft lip and palate. The Cleft Palate-Craniofacial Journal, 28, 172-178.

Chapman, K. L., Hardin-Jones, M., Schulte, J., \& Halter, K. A. (2001). Vocal development of 9-month-old babies with cleft palate. Journal of Speech, Language, and Hearing Research, 44, 1268-1283.

Choi, M. S., Kim, S. J., \& Kim, H. S. (2014). Lexical and phonology development in 2-year-old Korean children. Korean Journal of Early Childhood Special Education, 14, 133-152. 
Estrem, T., \& Broen, P. A. (1989). Early speech production of children with cleft palate. Journal of Speech, Language, and Hearing Research, 32, 12-23.

Ferguson, C. A., \& Farwell, C. B. (1975). Words and sounds in early language acquisition. Language, 51, 419-439.

Ha, S. (2014). Phonological characteristics of early vocabulary in young children with cleft palate. Phonetics and Speech Sciences, 6, 65-71.

Ha, S., \& Pi, M. (2016). Consonant frequency and phonological characteristics of eojeols in spontaneous speech samples from 18-to 30-month-old Korean children. Communication Sciences \& Disorders, 21, 567-579.

Hardin-Jones, M., \& Chapman, K. L. (2014). Early lexical characteristics of toddlers with cleft lip and palate. The Cleft Palate-Craniofacial Journal, 51, 622-631.

Hong, G. H., \& Kim, Y. T. (2005). A longitudinal study of predictors for expressive vocabulary development of late-talkers. Korean Journal of Communication Disorders, 10, 1-24.

Hutters, B., Bau, A., \& Brondsted, K. (2001). A longitudinal group study of speech development in Danish children born with and without cleft lip and palate. International Journal of Language \& Communication Disorders, $36,447-470$.

Jang, H. S., Seo, S. J., \& Ha, J. Y. (2008). Developmental assessment for the early intervention program planning. Seoul: Hakjisa.

Jung, K. H., Pae, S., \& Kim, G. (2006). The early phonological development of Korean children. Korean Journal of Communication Disorders, 11, 1-15.

Kim, H., Kim, Y. T., \& Kim, S. (2002). Language development in cleft palate infants. Korean Journal of Speech Sciences, 9, 121-131.

Kim, H., Lee, R., \& Lee, E. (2015). Phonological variability with consonant inventory size in late-talkers and normal children. Phonetics and Speech Sciences, 7, 175-181.

Kim, M. J. \& Pae, S. (2005). The percentage of consonants correct and the ages of consonantal acquisition for 'Korean - Test of Articulation for Children (K-TAC)'. Speech Sciences, 12, 139-149.

Kim, M., \& Ha, S. (2013). Longitudinal study of early vocalization development in toddlers with and without cleft palate from 6 to 18 months of age. Communication Sciences \& Disorders, 18, 223-234.

Kim, Y. T., Kim, K. H., Yoon, H. R., \& Kim, H. S. (2003). Sequenced Language Scale for Infants (SELSI). Seoul: Special Education Publishing.

Leonard, L. B. (2014). Children with specific language impairment (2nd ed.). Cambridge, MA: MIT Press.

Locke, J. L. (1983). Phonological acquisition and change. New York, NY: Academic Press.
Mirak, J., \& Rescorla, L. (1998). Phonetic skills and vocabulary size in late talkers: concurrent and predictive relationships. Applied Psycholinguistics, 19, 1-17.

Moon, H., \& Ha, S. (2012). Phonological development in toddlers with cleft palate and typically developing toddlers aged 12-24 months. Korean Journal of Communication Disorders, 17, 118-129.

Morris, H., \& Ozanne, A. (2003). Phonetic, phonological, and language skills of children with a cleft palate. The Cleft Palate-Craniofacial Journal, 40, 460470.

Pae, S., \& Kwak, K. C. (2011). Korean MacArthur-Bates Communicative Development Inventories (K M-B CDI). Seoul: Mindpress.

Park, B., \& Ha, S. (2016). Early vocalization and later phonological and expressive vocabulary development in children with and without cleft palate. Communication Sciences \& Disorders, 21, 355-370.

Paul, R. (1991). Profiles of toddlers with slow expressive language development. Topics in Language Disorders, 11, 1-13.

Paul, R. (1993). Patterns of development in late talkers: preschool years. Communication Disorders Quarterly, 15, 7-14.

Paul, R., \& Jennings, P. (1992). Phonological behavior in toddlers with slow expressive language development. Journal of Speech, Language, and Hearing Research, 35, 99-107.

Peterson-Falzone, S. J., Trost-Cardamone, J., Karnell, M. P., \& Hardin-Jones, M. A. (2006). The clinician's guide to treating cleft palate speech. St. Louis, MO: Mosby.

Rescorla, L. (1989). The language development survey: a screening tool for delayed language in toddlers. Journal of Speech and Hearing Disorders, 54, 587-599.

Rescorla, L., \& Achenbach, T. M. (2002). Use of the Language Development Survey (LDS) in a national probability sample of children 18 to 35 months old. Journal of Speech, Language, and Hearing Research, 45, 733-743.

Rescorla, L., \& Ratner, N. B. (1996). Phonetic profiles of toddlers with specific expressive language impairment (SLI-E). Journal of Speech, Language, and Hearing Research, 39, 153-165.

Rescorla, L., \& Schwartz, E. (1990). Outcome of toddlers with specific expressive language delay. Applied Psycholinguistics, 11, 393-407.

Scherer, N. J., Williams, A. L., \& Proctor-Williams, K. (2008). Early and later vocalization skills in children with and without cleft palate. International Journal of Pediatric Otorhinolaryngology, 72, 827-840.

Schwartz, R. G., \& Leonard, L. B. (1982). Do children pick and choose? An examination of phonological selection and avoidance in early lexical ac- 
quisition. Journal of Child Language, 9, 319-336.

Shin, H. J., \& Lee, E. J. (2015). Phonological characteristics of late-talkers through phonological whole-word analysis. Communication Sciences \& Disorders, 20, 157-165.

Shin, J. (2005). Phoneme frequency of 3 to 8 - year-old Korean children. Korean Linguistics, 27, 163-200.

Sim, H., \& Ha, S. (2014). Comparison of phonological development between typically developing children and late talking children aged 18-30 months. Communication Sciences \& Disorders, 19, 99-112.

Stoel-Gammon, C. (1985). Phonetic inventories, 15-24 months: a longitudinal study. Journal of Speech, Language, and Hearing Research, 28, 505-512.

Stoel-Gammon, C. (2011). Relationships between lexical and phonological development in young children. Journal of Child Language, 38, 1-34.

Storkel, H. L. (2006). Do children still pick and choose? The relationship between phonological knowledge and lexical acquisition beyond 50 words. Clinical Linguistics \& Phonetics, 20, 523-529.

Storkel, H. L., \& Morrisette, M. L. (2002). The lexicon and phonology: interactions in language acquisition. Language, Speech, and Hearing Services in
Schools, 33, 24-37.

Thal, D. J., Oroz, M., \& McCaw, V. (1995). Phonological and lexical development in normal and late-talking toddlers. Applied Psycholinguistics, 16, 407424.

Thal, D., \& Bates, E. (1988). Language and gesture in late talkers. Journal of Speech, Language, and Hearing Research, 31, 115-123.

Thal, D., Tobias, S., \& Morrison, D. (1991). Language and gesture in late talkers: a 1-year follow-up. Journal of Speech, Language, and Hearing Research, 34, 604-612.

Willadsen, E. (2013). Lexical selectivity in Danish toddlers with cleft palate. The Cleft Palate-Craniofacial Journal, 50, 456-465.

Williams, A. L., \& Elbert, M. (2003). A prospective longitudinal study of phonological development in late talkers. Language, Speech, and Hearing Services in Schools, 34, 138-153.

Yoon, M. S., Kim, J. M., \& Kim, S. J. (2013). Phonological whole-word measures of spontaneous speech in children two to four years of age. Journal of Speech \& Hearing Disorders, 22, 69-85. 


\section{국문초록}

\section{구개열 아동, 말 늦은 아동, 일반 아동의 초기 어휘에 나타난 음운 특성 피민경 1 하승희 ${ }^{2}$}

'한림대학교 대학원 언어병리청각학과, ${ }^{2}$ 한림대학교 언어청각학부, 한림청각언어연구소

배경 및 목적: 본 연구는 초기 어휘 및 음운 발달 상의 지연을 일반적으로 보이는 구개열 아동과 말 늦은 아동의 초기 어휘에 나타난 음 운 특성을 일반 아동과 비교해 살펴보았다. 방법: $18-30$ 개월 구개열 아동, 말 늦은 아동, 일반 아동 각 20 명의 자발화 중 연속 50 개 발화 를 기준으로 자음 목록 수, 조음위치 및 조음방법별 자음 산출 비율, 어절 첫 소리 유형과 어절 첫 자음 정확도를 구하여 집단 별 음운 특성을 비교하였다. 결과: 서로 다른 낱말 수는 구개열 아동이 말 늦은 아동에 비해 많았다. 자음 목록 수는 말 늦은 아동과 구개열 아 동 모두 또래에 비해 제한적이었다. 구개열 아동은 말 늦은 아동과 일반 아동에 비해 장애음과 파찰음의 산출 비율, 장애음과 폐쇄음으 로 시작하는 어절 비율이 낮았으며 어절 첫 자음 정확도가 낮았다. 말 늦은 아동은 구개열 아동, 일반 아동에 비해 유음 산출 비율이 낮 았으나 공명 자질 유무에 따른 산출 비율 및 말소리 산출 정확성은 일반 아동과 유사하였다. 논의 및 결론: 본 연구는 말 늦은 아동이 표현어휘 수와 자음 목록과 음절 구조 면에서, 구개열 아동은 장애음 산출 제약 및 말소리 산출 정확성 면에서 상대적으로 제한되어 있 음을 제시하고 있다.

핵심어: 초기 어휘, 음운 특성, 구개열 아동, 말 늦은 아동

\section{참고문헌}

김민영, 하승희(2013). 6-18개월 구개열 영유아와 일반 영유아의 발성 발달에 관한 종단연구. 언어청각장애연구, 18, 223-234.

김민정, 배소영(2005). ‘아동용 조음검사를 이용한 연령별 자음정확도와 우리말 자음의 습득연령. 음성과학, 12, 139-149.

김영태, 김경희, 윤혜련, 김화수(2003). 영유아 언어발달 검사(SELSI). 서울: 도서출판 특수교육.

김혜진, 이란, 이은주(2015). 말 늦은 아동과 일반 아동의 자음 목록 크기에 따른 음운변이성. 말소리와음성과학, 7, 175-181.

김효선, 김영태, 김석화(2002). 구개파열 영유아의 언어발달 특성 연구.음성과학, 9, 121-131.

문희원, 하승희(2012). 12-24 개월 구개열 유아와 일반 유아의 음운발달. 언어청각장애연구, 17, 118-129.

박보라, 하승희(2016). 구개열, 일반 영유아의 초기 발성 및 음운, 표현어휘 발달 비교. 언어청각장애연구, 21, 355-370.

배소영, 곽금주(2011). 한국판 맥아더-베이츠 의사소통발달평가(K M-B CDI). 서울: 마인드프레스.

신지영(2005). 3 세-8 세 아동의 자유 발화 분석을 바탕으로 한 한국어 말소리의 빈도 관련 정보. 한국어학, 27, 163-200.

신화정, 이은주(2015). 단어단위 음운분석에 의한 말 늦은 아동의 음운 특성. 언어청각장애연구, 20, 157-165.

심혜림, 하승희(2014). 18-30 개월 말 늦은 아동과 일반 아동의 음운 발달 비교. 언어청각장애연구, 19, 99-112.

윤미선, 김정미, 김수진(2013). 자발화 문맥에서의 단어단위 음운 평가. 언어치료연구, 22, 69-85.

장유경(2004). 한국 영아의 초기 어휘발달: 8개월-17개월. 한국심리학회지: 일반, 23, 77-99.

장혜성, 서소정, 하지영(2008). 영아선별 교육진단검사. 서울: 학지사.

정경희, 배소영, 김기숙(2006). 12, 18, 24개월 영유아의 음운발달 특성. 언어청각장애연구, 11, 1-15.

최민실, 김수진, 김효선(2014). 2세 전후반의 어휘능력과음운능력 자발화를 중심으로. 유아특수교육연구, 14, 133-152.

하승희(2014). 구개열 아동의 초기 어휘에 나타난 음운 특성 연구. 말소리와 음성과학, 6, 65-71.

하승희, 피민경(2016). 18-30개월 한국 아동의 자발화에 나타난 자음 빈도와 어절 첫소리 특성. 언어청각장애연구, 21, 567-579.

홍경훈, 김영태(2005). 종단연구를 통한 말늦은 아동의 표현어휘발달 예측요인 분석. 언어청각장애연구, 10, 1-24. 